\title{
La Exposición Misional Vaticana de 1925, los misioneros salesianos y la representación del Oriente ecuatoriano*
}

The 1925 Vatican Missionary Exposition, the Salesian missionaries, and representation of Ecuador's Oriente (Amazon Region)

A Exposição Missionária Vaticana de 1925, os salesianos e a representação da Amazônia equatoriana

Chiara Pagnotta

Universidad de Barcelona (España)

cpagnotta@gmail.com

DOI: http: / / dx.doi.org/10.29078/rp.v0i47.676

Fecha de recepción: 19 de noviembre de 2017

Fecha de aceptación: 3 de febrero de 2018

Artículo de investigación

* Este trabajo se enmarca en el proyecto de investigación I+D+i HAR2015-64891-P (MINECO/FEDER, UE), que se desarrolla en el seno del TEIAA, grupo de investigación consolidado por el Comissionat per a Universitats i Recerca del DIUE de la Generalitat de Catalunya. Agradezco a los evaluadores anónimos los comentarios y sugerencias. 
Este artículo estudia las representaciones sobre el Oriente ecuatoriano y sus habitantes en la exposición organizada en Roma. En dicho acontecimiento se exhibieron objetos reunidos por comunidades religiosas de diferentes territorios misioneros a nivel mundial. En el caso ecuatoriano, la colección provino del Vicariato Apostólico de Méndez y Gualaquiza, donde los salesianos desarrollaban su ministerio. La muestra de objetos culturales revela cómo se veía a estos grupos indígenas, y el papel que se autoasignaba la Iglesia católica en los campos religioso, científico y cultural.

Palabras clave: historia latinoamericana, historia de la Iglesia, comunidad salesiana, Exposición Misional Vaticana, Vicariato Apostólico de Méndez y Gualaquiza, representaciones indígenas, Oriente ecuatoriano, siglo $\mathrm{XX}$.

\section{ABSTRACT}

This article examines the representations of Ecuador's Oriente and its inhabitants in the exposition organized in Rome. At this event, objects collected by the religious communities from various missionary territories throughout the world were exhibited. In the case of Ecuador, the collection came from the Apostolic Vicariate of Méndez and Gualaquiza, where the Salesians were carrying out their ministry. The sample of cultural objects on display highlights how these indigenous groups were viewed and what role the Catholic Church had been assigned to play in religious, scientific, and cultural matters.

Keywords: Latin American history, history of the Church, Salesian community, Vatican Missionary Exposition, Apostolic Vicariate of Méndez and Gualaquiza, indigenous representations, Ecuador's Oriente, twentieth century

RESUMO

O artigo estuda as representações sobre a Amazônia equatoriana e seus povos na exposição Vaticana em Roma. Naquele espaço, foram exibidos objetos coletados pelas comunidades religiosas que trabalhabam em distintos territórios a nível mundial. No caso equatoriano, a coleção veio do Vicariato Apostólico de Méndez y Gualaquiza, onde os salesianos desenvolviam seu trabalho de evangelização e educação. A seleção de objetos mostra como os povos indígenas foram vistos pelos salesianos, além do papel que a Igreja se auto arrogara nos âmbitos religioso, científico e cultural.

Palavras chave: Historia Latinoamericana, História da Igreja, comunidade salesiana, Exposição Missionária Vaticana, representações indígenas, Amazônia equatoriana, século XX. 


\section{INTRODUCCIÓN}

Las exposiciones universales alcanzaron un rol protagónico a lo largo del siglo XIX y principios del siglo XX. ${ }^{1}$ Estas pretendían mostrar los avances de los diferentes países que participaban en ellas en el campo tecnológico, agrícola y artístico y, en general, se regían por la idea de progreso en boga durante la época. ${ }^{2}$

Por parte del mundo católico, el interés por las exposiciones determinó, incluso, el hecho de que se adoptaran para ellas las formas de comunicaciones modernas del periodo, ${ }^{3}$ dando lugar, en particular, a la puesta en escena de peculiares formas de etno-exposiciones de carácter religioso. Estas exposiciones fueron lugar de representaciones de las poblaciones indígenas por parte de los misioneros que desarrollaban entre ellas su obra evangelizadora, civilizatoria y educadora, y cuyos resultados fueron expuestos en imágenes y objetos de cultura material, entre otros. ${ }^{4} \mathrm{El}$ interés del mundo católico por la exhibición pública de los logros alcanzados por los misioneros llegó a su máxima expresión en la Exposición Misional Vaticana, con ocasión del año Santo (diciembre 1924-enero 1926). Para exhibirlos en ella, el salesiano padre Carlo Crespi había recopilado -a partir de 1923- varios objetos procedentes del Vicariato Apostólico de Méndez y Gualaquiza en Ecuador.

Cabe destacar que desde los años veinte del siglo $\mathrm{XX}$, los misioneros salesianos se convirtieron en importantes actores para la implementación de la evangelización y la civilización de la zona amazónica del país andino, ${ }^{5}$

1. Paul Greenhalgh, Ephemeral Vistas: The Expositions Universelles, Great Exhibitions and World's Fairs, 1851-1939 (Manchester: Manchester University Press, 1988).

2. Sobre la idea de progreso, véase John Bury, The Idea of Progress: An Inquiry Into Its Origins and Growth (Nueva York: Dover Publications, 1932). Estas exposiciones, además, eran funcionales al fomento de las industrias, el comercio y la apertura de nuevos mercados económicos para los países expositores y para los anfitriones. Leoncio López-Ocón, "La América Latina en el escenario de las Exposiciones Universales del siglo XIX", Procesos: revista ecuatoriana de historia, n. ${ }^{\circ} 18$ (enero-junio 2002): 104.

3. Guido Abbattista, Umanità in mostra. Esposizioni etniche e invenzioni esotiche in Italia (1880-1940) (Trieste: Edizioni Università di Trieste, 2013).

4. Se entiende en este caso la representación como la materialización de las concepciones culturales del momento. Para más detalles, véanse los estudios clásicos de Roger Chartier, "Le monde comme représentation", Annales. Économies, Sociétés, Civilisations 44, n. ${ }^{\circ} 6$ (1989) y Louis Marin, Des pouvoirs des images (París: Éd. du Seuil, 1993).

5. Chiara Pagnotta, "'Evangelizar' y 'civilizar' la Amazonía ecuatoriana. Una aproximación a la actividad del salesiano Carlo Crespi en la década de 1920". En La reinvención de América. siglos XIX-XX, ed. por Pilar García Jordán, 125-149 (Barcelona: Edicions UB / TEIAA, 2017). Utilizamos el término "Oriente" tal como era costumbre en la época trata- 
aunque ya desde 1893 los religiosos desarrollaban su obra misional en el Vicariato con los "jíbaros". ${ }^{6}$ Anteriormente, en la década de 1860, con el gobierno de García Moreno se había pensado en la utilización de las misiones católicas como vanguardia civilizadora. Luego, la reaparición de las misiones como funcionales al fortalecimiento del proyecto inclusivo-civilizatorio de la población indígena se produjo en la década de 1880. Para entonces, el gobierno presidido por José María Plácido Caamaño, a través del subsecretario de Educación Carlos Rodolfo Tobar, planteó al Congreso de 1885 la conveniencia de la llegada de los salesianos al Ecuador. No fue sino hasta febrero de 1887 que se firmó el contrato entre el gobierno y Don Bosco, con la finalidad de crear un instituto salesiano para la educación de los jóvenes ecuatorianos. Hay que remarcar que a partir de este mismo año empezaron a ser publicados en el Bollettino Salesiano artículos que narraban los acontecimientos de los salesianos en Ecuador. ${ }^{7}$

da, y es reflejado en los documentos correspondientes, aunque, en la década de los veinte, el Vicariato Apostólico encargado a los salesianos abarcaba el territorio de la Gobernación del Sur del Oriente en el que vivían los pueblos Shuar.

6. Entre otros: Chiara Pagnotta, “Los salesianos y los jíbaros. Imágenes sobre el primer viaje de exploración al Oriente ecuatoriano (1893)". En El mundo latinoamericano como representación, siglos XIX-XX, ed. por Pilar García Jordán, 57-176 (Barcelona: Ediciones UB / TEIAA / IFEA, 2015). Jíbaro es el término despectivo utilizado en la época colonial, aplicado más o menos a todos los indios que vivían entre los Andes, el río Pastaza y el Marañón. Para más informaciones sobre los grupos jíbaros véase el clásico estudio de Paul Rivet, "Les Indiens Jibaros. Etude géographique, historique et ethnographique", L'Anthropologie, 19 (1907): 333-368, y también: Anne-Christine Taylor, "El Oriente ecuatoriano en el siglo XIX: 'el otro litoral' ". En Historia y región en el Ecuador: 1830-1930, ed. por Juan Maiguashca, 17-68 (Quito: FLACSO Ecuador / York University / Instituto Francés de Estudios Andinos / Corporación Editora Nacional, 1994), y Anne-Christine Taylor, “Una categoría irreducible en el conjunto de la naciones indígenas: los jíbaros en las representaciones occidentales". En Imágenes e imagineros. Representaciones de los indígenas ecuatorianos, siglos XIX y XX, ed. por Blanca Muratorio, 75-107 (Quito: FLACSO Ecuador, 1994).

7. Así, el Bollettino Salesiano se refiere a la futura instalación de los salesianos en el país andino: "A la ciudad de Quito, que es la capital, en octubre del próximo mes [Don Bosco] comenzará a enviar un destacamento de Salesianos para abrir una casa de Artes y oficios para el beneficio de los pobres de la República y también de los italianos allí residentes. D. Bosco, además de prever las necesidades presentes, prepara a la Providencia para las necesidades futuras. Precede al conjunto de los italianos, que después de la corte del istmo emigran en esas partes, en donde los adultos se reunirán con los hermanos, y los jóvenes encontrarán a los maestros, los concejales, los padres en los salesianos, que cuidaran de ellos, hablarán el idioma, los amaestrarán y ayudarán a mantener viva la memoria de la madre patria. ¡Qué pensamiento tan feliz! Ni su celo se limitará a esto solo; pero se extenderá a las tribus de los salvajes, que todavía existen entre las gargantas de las altas montañas, desconocedoras de Dios y de todos los principios de civilización. De la capital de la República, como de un centro de operaciones, como un cuartel general, los Salesianos se trasladarán a la exploración de otras tierras y las conquistarán a la religión y a la civili- 
Por parte de los poderes civiles ecuatorianos, hay que matizar que fue a partir de los gobiernos liberales (1895-1925) que el control de la región amazónica empezó a convertirse en un tema de interés geopolítico y, consecuentemente, en un ingrediente fundamental del proyecto político orientado a la construcción de la nación ecuatoriana. Estos gobiernos decretaron la expulsión de los salesianos del Ecuador (1896) bajo la acusación de haber apoyado a la facción conservadora en la lucha contra Eloy Alfaro. Solo a los salesianos presentes en Gualaquiza se les permitió permanecer en el territorio, y en circunstancias de recorte de fondos para su misión. Concuerdo con Bottasso cuando expone que los liberales permitieron quedarse a los religiosos en la región tras considerar que estos llegaban a zonas a las que los funcionarios estatales se resistían a ir y porque, además, los misioneros podían ser útiles en el control de los indígenas no sometidos. ${ }^{8}$ La expropiación de los bienes salesianos dio origen a un arbitraje internacional (1899) que se pronunció por la condena al Ecuador. Finalmente, los salesianos volvieron a Guayaquil en $1901 .^{9}$

Es oportuno matizar que el historiador francés Pierre Nora otorga a los lieux de mémoire (museos, monumentos, archivos y celebraciones) mucha importancia, en cuanto son escenarios de una representación en la que el tiempo reviste una función simbólica -más que una realidad histórica- bajo la influencia determinante de un colectivo que los implementa con sus afectos y sus emociones. ${ }^{10}$ Además, en América Latina es evidente la lucha por el control de las imágenes producidas y reproducidas, pues esto acompañó de

zación, beneficiando así a la prosperidad del Estado, consolando la Iglesia de los nuevos hijos, regocijando el cielo con las almas electas". (Todas las traducciones del italiano al castellano son obra de la autora). "D. Bosco e i Salesiani nella Repubblica dell'Equatore". Bollettino Salesiano XI, n. 9 (septiembre 1887): 105. Resalta cómo para el caso de nuestro interés, en el Bollettino aparezcan pocas informaciones respecto a la Exposición Misional Vaticana. No fue este el caso de la Exposición Misional Salesiana de 1926, propia de la congregación, objeto de otro escrito de la autora: Chiara Pagnotta, "La mise en scène del proyecto salesiano en el Suroriente ecuatoriano. La Exposición Etnográfica del Oriente (Guayaquil, 1924) y la Exposición Misional Salesiana (Turín, 1926)", inédito.

8. Juan Bottasso, coord., Los salesianos y la Amazonía. Actividades y presencia, t. III (Quito: Abya-Yala, 1993), 87.

9. Hasta 1924, la red de las misiones salesianas se había difundido en la Patagonia (República Argentina), Pampa Central (República Argentina), Vicariato Apostólico de Magellan (Chile), Vicariato Apostólico de Méndez y Gualaquiza (Ecuador), Vicariato Apostólico de Shiuchow (Cuantung-China), Vicariato Apostólico del Kimberley (Australia), la Prelatura de Registro de Araguaya (Brasil), Prefectura Apostólica del Río Negro (Argentina), Prefectura Apostólica de Assam (India)" y en varios centros de misiones, como en Congo Belga, el distrito de Heung-Shan, el Chaco Paraguayo, y otros en Oriente. "I campi delle missioni estere salesiane", Bollettino Salesiano XLVIII, n. ${ }^{\circ} 2$ (febrero 1924): 35-37.

10. Pierre Nora, Les lieux de mémoire (París: Gallimard, 1997). 
manera trascendente al proceso de colonización de los imaginarios indígenas. ${ }^{11}$ Matiza el historiador Peter Burke que "cuando se produce un encuentro entre culturas distintas, lo más probable es que las imágenes que una crea de la otra sean estereotipadas", ${ }^{12}$ entendiendo por estereotipo un recordatorio de los vínculos entre imagen visual y mental, a menudo con tendencia a exagerar determinados elementos omitiendo otros. Precisamente, para el caso ecuatoriano a finales del siglo XIX, ya Blanca Muratorio destacaba cómo la representación del indígena que se había hecho visible en el panteón de la nacionalidad en construcción no era la de un personaje real, sino que se trataba, más bien, de la imagen del inca, abstracta y fuera del tiempo histórico, la cual contribuía a rastrear los orígenes del país hacia una nobleza indígena (real o ficticia) y dejaba así en las sombras a los indígenas de carne y hueso. ${ }^{13}$ En este mismo sentido, Peter Burke destaca de qué manera los indios de Brasil aparecían -en algunos grabados holandeses del siglo XVII- asimilados a los bárbaros del mundo antiguo y, por ende, representados armados con arcos y flechas de época clásica. ${ }^{14}$

En esta línea teórica, y conforme a lo afirmado por la antropóloga Deborah Poole, el ver y el representar aparecen como actos materiales, en la medida en que construyen medios de intervención en el mundo, y crean una hegemonía entre quien ve primero y luego representa; y el sujeto de la mirada. ${ }^{15}$ Finalmente, siguiendo a Linda Aimone y Carlo Maria Olmo, cabe destacar que las exposiciones no se presentan como acontecimientos unitarios, sino que más bien desvelan tramas, a veces inesperadas, de una narración muy discontinua. ${ }^{16}$

Por estas razones, trato aquí de mostrar el mapa que está detrás de la Exposición Misional Vaticana y la exhibición que se hace en ella de los objetos recopilados en Ecuador, para tratar de desvelar la trama que otorga sentido a la exposición misma. En este trabajo pretendo, por un lado, acercarme al contenido y a los objetivos de la Exposición Misional Vaticana celebrada en Roma, entre diciembre de 1924 y enero de 1926, para luego analizar las

11. Serge Gruzinski, La guerre des images de Christophe Colomb à "Blade Runner" (14922019) (París: Fayard, 1990).

12. Peter Burke, Eyewitnessing. The Uses of Imagies as Historical Evidence (Londres: Reaktion Books, 2001), 158.

13. Blanca Muratorio, “Nación, identidad y etnicidad: imágenes de los indios ecuatorianos y sus imagineros a fines del siglo XIX". En Imágenes e imagineros...

14. Burke, Eyewitnessing..., 155.

15. Deborah Poole, Vision, Race and Modernity. A Visual Economy of the Andean Image World (Princeton: Princeton University Press, 1997).

16. Linda Aimone y Carlo Maria Olmo, Le esposizioni universali, 1851-1900: il progresso in scena (Turín: Umberto Allemandi \& Co., 1990), 9. 
imágenes y la representación del suroriente ecuatoriano y de sus habitantes llevada a cabo por los salesianos en dicha exposición.

Las hipótesis de trabajo aquí planteadas son que en la exposición etnológica el foco de atención estuvo dirigido hacia el misionero como mártir y héroe, en el contexto del proceso civilizatorio que se estaba implantando en los diferentes territorios. En este sentido, lo indígena, los diferentes grupos étnicos y las representaciones de la cultura material son mostrados en la Exposición para justificar y reforzar la actuación de los misioneros en la tentativa de reconquista de aquella hegemonía cultural que la Iglesia de inicios del siglo XX había perdido. En segundo lugar, planteo que la Exposición fue un instrumento que la Iglesia utilizó para situarse en el contexto del desarrollo de disciplinas -en particular la etnología- de matriz católica que pudieran coadyuvar a las labores misionales desde un punto de vista científico. Finalmente, planteo que las representaciones exhibidas fueron utilizadas, una vez más, como evidencia visual de la trasformación del mundo "salvaje" hacia el "civilizado" gracias a la infatigable labor de los misioneros.

Las fuentes utilizadas para este estudio provienen de las investigaciones llevadas a cabo en el Museo Etnologico Missionario di Colle Don Bosco, en el que he podido revisar los objetos que ahí quedaron entre los enviados desde Ecuador por el padre Carlo Crespi para la Exposición Vaticana; en el Archivio Salesiano Centrale en Roma y en el Archivo Documental y Fotográfico Salesiano de Quito, donde he recogido material y documentos sobre la obra salesiana en Ecuador para la época tratada en este ensayo; en la Biblioteca Pública Episcopal del Seminari Conciliar de Barcelona en la que he podido consultar la Rivista Illustrata della Esposizione Missionaria Vaticana, revista oficial de la Exposición, los Annali Lateranensi; y, finalmente, en la revista El Siglo de las Misiones.

Por estas razones, en el primer apartado trataré de reconstruir el contexto católico en el que se desarrolla el proyecto de la Exposición. En segundo lugar, analizaré la exhibición de los objetos; y finalmente me centraré en los objetos provenientes de Ecuador y su representación. ${ }^{17}$

17. Para un estudio más específico sobre los salesianos en el Vicariato Apostólico de Méndez y Gualaquiza, véase, entre otros, Juan Bottasso, coord., Los salesianos y la Amazonía, t. I, II y III (Quito: Abya-Yala, 1993) y el más reciente de Lola Vázquez et al., coords., La presencia salesiana en Ecuador. Perspectivas históricas y sociales (Quito: Abya-Yala, 2012). 


\section{LA EXPOSICIÓN EN EL CONTEXTO MISIONAL CATÓLICO}

En diciembre de 1924 (y hasta enero de 1926) tuvo lugar la Exposición Misional Vaticana que coincidió con el año jubilar (1925). El estudioso Sánchez Gómez atestigua dos motivaciones que empujaron al "Papa de las Misiones" (Pío XI) a realizar dicha puesta en escena: las consecuencias de la Primera Guerra Mundial y, sobre todo, la necesidad de enfrentarse al modernismo con nuevas y más eficaces armas. ${ }^{18}$ Por un lado, se pretendía demostrar que la religión era compatible con los avances científicos que se estaban dando y, por otro, se pretendía hacer de las instituciones de la Iglesia instrumentos de modernización y progreso útiles a los demás actores de la época. En suma, se trataba de modernizar la Iglesia, su imagen y su actuación para reconquistar su primacía espiritual y material.

Cabe destacar que, anteriormente, desde mediados del siglo XIX, la Iglesia católica había atestiguado cómo se reducían sus espacios de acción a causa de las reformas liberales que habían tenido lugar en Europa y en gran parte de América Latina. Por ende, bajo el pontificado de León XIII (1878-1903) se había llevado a cabo una actualización acorde con la época, sosteniendo que la religión era compatible con el progreso, pues podía ser útil a los estados en su tarea educadora y civilizadora de los grupos subalternos, tanto en Europa como en varias partes del globo.

Fue posteriormente, bajo el pontificado de Pío XI (1922-1939), que la política misional estuvo enfocada específicamente en la restitución de la supremacía de la Iglesia en el campo mundial. En ese contexto, adquiere una nueva importancia la formación del misionero en las disciplinas sacras y las profanas, y en particular en la etnología. ${ }^{19}$

Sin duda alguna, la persona que pudo levantar el estandarte de la etnología religiosa -en polémica con el evolucionismo- fue el sacerdote de la Sociedad del Verbo Divino, etnólogo y misionero Wilhelm Schmidt. Él fue profesor de Etnología y Lingüística en la Universidad de Viena y exponente

18. Luis Ángel Sánchez Gómez, "Por la etnología hacia Dios: la Exposición Misional Vaticana de 1925", Revista de Dialectología y Tradiciones Populares LXII, n. 2 (julio-diciembre 2007): 64-65. Entendemos por "modernismo" una tendencia del pensamiento católico entre los siglos XVIII y XIX a la que la Iglesia necesitaría de una adecuación al paso del tiempo, tratando de conciliar la fe con las instancias del hombre moderno. El modernismo recibió censuras por parte de las jerarquías eclesiásticas, entre ellas la Encíclica Pascendi Dominici Gregi del Papa Pío X (1907).

19. Alba Rosa Leone, "La politica missionaria del Vaticano tra le due guerre", Studi Storici 21, n. $^{\circ} 1$ (1980): 134-135. 
en primer plano de la escuela cultural historicista -también conocida como teoría historicista del Difusionismo cultural- de Viena. Además, fue el fundador de la revista Anthropos (1906), especializada en etnología, lingüística e historia de las religiones que publicaba artículos en alemán, inglés, francés, italiano, español y latín. En sus trabajos, Schmidt difundió la teoría del primitivo monoteísmo en base a la idea de que, originalmente, existía un único ser supremo cuyas características eran la eternidad, la omnisciencia, la bondad, la moralidad, la omnipotencia y el poder creador. Es preciso destacar que Schmidt recuperó lo afirmado por Andrew Lang en 1898 cuando atestiguó la existencia de un ser supremo respecto a los pueblos primitivos, refutando la idea de que el animismo estuviera en el origen de todas las religiones. Por ende, Schmidt propuso la idea de un mensaje original de Dios que se habría perdido, la idea de una sociedad y de un mundo que se habría corrompido hasta llegar a lo que era en ese momento. ${ }^{20}$ Después de la anexión de Austria (13 de marzo de 1938), Schmidt y el Instituto Anthropos se trasladaron a Suiza donde él pasó a ser profesor de la Universidad de Friburgo.

La teoría de Schmidt aparece indudablemente funcional al proyecto de recuperación de la supremacía católica a nivel mundial, ya que, conforme a la afirmación del monoteísmo primordial, todos los pueblos serían, en su base, monoteístas, y el trabajo de los misioneros en las distintas partes del mundo estaría dirigido a la recuperación de aquellas antiguas creencias que se corrompieron con el paso del tiempo. Nos interesa particularmente destacar aquí el ligamen de Schmidt con las jerarquías católicas, que se concretó en su papel durante y después de la Exposición: el Vaticano, en aquella época, resultó presentar las teorías de Schmidt como la prueba etnológica de la existencia de Dios y, por ende, el estudioso fue llamado a inaugurar la Exposición Vaticana. ${ }^{21}$

La particularidad de la Exposición fue que en ella se presentaron pabellones dedicados a la historia y a las conquistas misionales, junto con un gran pabellón de etnología que fue encargado, por deseo del Papa, a Schmidt, quien contó con completa libertad de exposición, juicio, etc.

La tentativa era dar a conocer las labores misionales a través de la puesta en escena de más de 100.000 objetos provenientes de los diversos lugares en los que actuaban los misioneros católicos. La Exposición -ubicada en los jardines vaticanos- ocupaba una superficie de 17.000 metros cuadrados, 7.000

20. Andrew Lang, The Making of Religion (Londres / Nueva York / Bombay: Longmans Green \& Co., 1898), https: / / ia601407.us.archive.org/13/items/makingofreligion00langiala/makingofreligion00langiala.pdf; Guillermo Schmidt, Manual de historia comparada de las religiones. Origen y formación de la religión. Teorías y hechos (Madrid: Espasa Calpe, 1941).

21. Vittorio Lanternari, Antropologia religiosa. Etnologia, storia, folklore (Bari: Edizioni Dedalo, 1997), 107. 
en plano y 10.000 en vertical, y estaba constituida por 24 pabellones, en los que se expusieron más de 100.000 objetos y documentos variados (figura 1). ${ }^{22}$ Se trataba de un conjunto de fotografías, mapas, libros, y hallazgos prehistóricos y arqueológicos, que incluía obras de arte, objetos de uso cotidiano y ceremonial, modelos de templos, habitaciones "tradicionales", etc. ${ }^{23}$ que, según monseñor Pietro Ercole, director administrativo de Museo del Letrán, debían dar "la visión -como en un cuadro sintético- de todo el mundo infiel en su gran variedad de razas y tribus, de religiones, de arte, de costumbres, de vida doméstica y social para hacer comprender mejor [...] la necesidad y la urgencia de hacerse cooperadores de los misioneros en el apostolado de fe y de civilidad". ${ }^{24}$

La Exposición estuvo organizada en una parte general subdividida en el pabellón de historia de las misiones, el pabellón de etnología y lingüística y el pabellón de estadística general; y en otra parte que recogía la distribución geográfica de las misiones. Podemos ver cómo los objetos expuestos fueron el medio a través del cual se desarrolló el discurso misionero; hay que matizar que estos fueron clasificados primero según unos criterios geográficos y según la misión de procedencia, así como basados en el orden que dieran a los misioneros por otro, siendo lo indígena un aspecto bastante ausente en las clasificaciones.

Teniendo un valor eminentemente educativo para el público que visitó la exposición, el recorrido empezaba idealmente en el territorio de origen de la religión católica, y se desarrollaba según un recorrido didáctico explicativo entre salas y pabellones. Después de un primer pabellón sobre la Tierra Santa seguía la exposición de la historia de las misiones, la sala de los mártires, el pabellón de etnografía y etnología, el de la América septentrional y central; tres espacios para la biblioteca misional, y uno sobre la ritualidad oriental; el de Propaganda Fide y estadística; otro sobre la ritualidad oriental; el de América meridional, el de Asia menor; el de India y Ceilán; el de Indochina; un espacio sobre las actividades de las misiones en Europa, y otro sobre la "contribución científica y obra civilizadora de las misiones"; el que se centraba en la Obra Pontificia de la Santa Infancia, el de las obras nacionales auxiliares de las misiones, el concerniente a la obra de San Pedro Apóstol y el de la obra apostólica; otro espacio para las obras nacionales auxiliares

22. Pietro Ercole, “Dall’Esposizione Vaticana al Museo Missionario Etnologico del Laterano", Annali Lateranensi I (1937): 10.

23. Ester Maria Console, "Incontri tra culture nelle collezioni del Museo Missionario Etnologico". En I Musei Vaticani 1929-2009: nell'80ªnniversario della firma dei Patti lateranensi, ed. por Antonio Paolucci y Cristina Pantanella, 169-178 (Roma / Florencia: Musei Vaticani / Giunti \& Livorno / Sillabe, 2009).

24. Ercole “Dall'Esposizione Vaticana...", 9. 


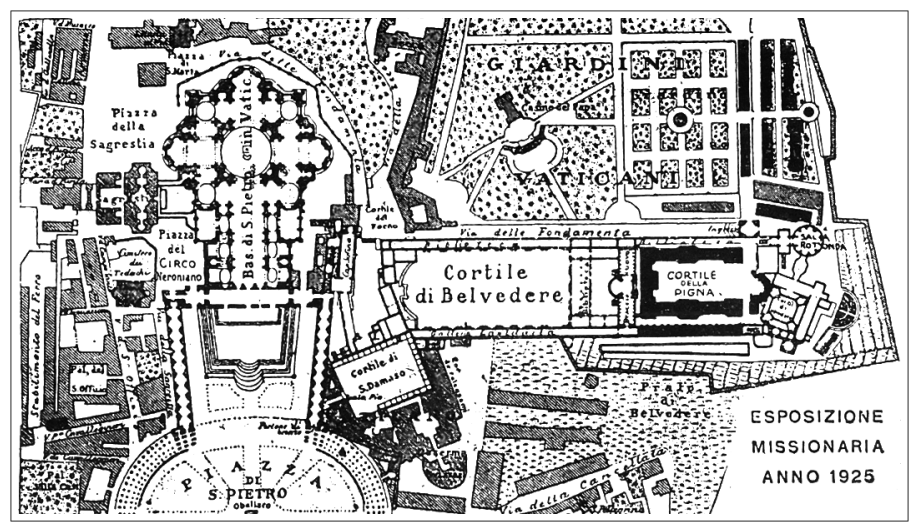

Figura 1. Planta general de las áreas vaticanas. Los signos negros indican las construcciones para la Exposición.

Fuente: "L'organizzazione della mostra". Rivista Illustrata dell'Esposizione Missionaria Vaticana 1, n. $^{\circ} 1$ (15 de dicembre 1924): 59-61.

de las misiones; una sección médica; un espacio sobre China, otro sobre Corea, uno sobre Asia insular, otro sobre Japón y Filipinas; uno dedicado al África central y austral, otro sobre África septentrional y Central; otro intitulado "La vida en Bagdad"; una sala dedicada a un bufé; los de la dirección, los despachos de la Rivista Illustrata dell' Esposizione Missionaria Vaticana, los despachos del personal, los de ventas, y otro para los billetes. ${ }^{25}$ Las salas comprendidas entre n. ${ }^{\circ} 1$ y n. ${ }^{\circ} 14$ estaban ubicadas alrededor del Cortile della Pigna, mientras que los otros espacios aparecían ubicados de manera lateral con respecto a los primeros.

Es evidente que el elemento geográfico, según una repartición continental, determinaba el destino de los objetos en las diferentes salas compartidas por diversas órdenes misionales. De esta manera, como para el caso del pabellón de América meridional, se muestra la obra de los misioneros salesianos, franciscanos y capuchinos en sus diferentes territorios de misiones, pero en detrimento de la obra y la historia de un particular instituto misional en un determinado territorio y sobre un determinado pueblo, y a favor de la emergencia de una imagen de unidad de acción de los misioneros en los pueblos misionados, bajo el paraguas de la religión católica.

25. "L'organizzazione della mostra", Rivista Illustrata dell'Esposizione Missionaria Vaticana 1 (15 de diciembre 1924): 24. 
Destaca ya desde su primer número la Rivista Illustrata della Esposizione Missionaria Vaticana, revista oficial de la Exposición:

Nunca antes se había pensado en una Exposición Universal de las Misiones, es decir en una reseña mundial de lo que se hace no únicamente por parte de esta o de la otra Congregación religiosa, de esta o de otra Nación, en esta o en otra parte del mundo, más bien por parte de toda la Iglesia y precisamente de todos los Misioneros Católicos en todo el universo para acelerar la llegada del Reino de Dios y la participación de todos los hombres a la Redención. ${ }^{26}$

Esta participación de todos los institutos religiosos, bajo el lema de la unidad en el catolicismo, era precisamente uno de los objetivos de la exhibición. Entre todos los pabellones y los objetos expuestos destacaba el papel del misionero, su obra y su constante sacrificio para con las conversiones de los "infieles". El resultado final era que entre la historia de las misiones y etnología no aparecían diferencias, aunque lo indígena resultaba invisibilizado, o puesto en segundo plano, en favor de la puesta en escena del proyecto misionero hacia los indígenas. Matizaba más detalladamente la imprenta De Agostini al señalar que: ${ }^{27}$

La Exposición misional, establecida en el Vaticano con ocasión del Año Santo, pretende proponer bajo el ojo de los fieles de todas partes del mundo lo que se hizo y lo que se hace por las Misiones y en las Misiones para despertar e intensificar el interés de todos respecto al grave y noble problema de la conversión de los infieles. De este modo, el visitante se hace una idea exacta de la labor de los misioneros, del medio físico y moral en el que eso se desarrollaba, de las numerosas dificultades que se encontraban allí, así como de los logros y de lo mucho que quedaba por hacer. ${ }^{28}$

Aquí se daba a conocer, claramente, la visión de la alteridad que tendía a reproducir dicha exposición, por ejemplo, en la contraposición entre fieles e infieles: teniendo los fieles que interesarse por el trabajo de los misioneros para la conversión de los infieles en las tierras lejanas, se dejaba entrever, tal vez con otro lenguaje, la distinción entre "civilizados" y "salvajes".

26. La Direzione [de la revista], "Lo spirito ed il programma della nostra rivista". Ibíd., 5 .

27. El grupo editorial De Agostini fue fundado en 1901 por el geógrafo italiano Giovanni de Agostini, hermano del salesiano, cartógrafo, etnólogo y explorador Alberto Maria de Agostini. En todo caso, el grupo editorial mantuvo a lo largo de su historia su carácter laico, por lo que hay que destacar que no se trataba de una imprenta religiosa.

28. Cesare Rossi y Marco Boroli, Calendario Atlante delle Missioni Cattoliche. Esposizione Missionaria Vaticana (Novara: Istituto Geografico De Agostini, 1925), 3. Las traducciones del francés y del inglés son obra de la autora. 
Por ende, la Exposición intentaba abrir una ventana sobre el mundo, ya que "el día de un movimiento de masa de los católicos del mundo, para la victoria de los miles de millones de almas aún no convertidas, sólo ahora amanece". ${ }^{29}$

Por otro lado, la idea de que los misioneros fueran unos agentes de civilización era abordada de forma que se trataban temas que concernían a las trasformaciones de los pueblos evangelizados gracias a los misioneros y a los pasos que aún quedaban por dar: "Entrad por ejemplo adentro de los pabellones de África o de Oceanía, contemplad estas escenas de antropofagia, [...] estudiad este tipo de caníbales [...] luego dad la vuelta, en el mismo pabellón, hacia estos retratos de cristianos metamorfoseados, [...] y medid, si podéis, el camino recorrido". ${ }^{30}$

\section{LOS OBJETOS: ENTRE ORGANIZACIÓN, EXHIBICIÓN Y FINALIDAD}

Las informaciones indican que la mayor parte de los objetos enviados a la Exposición iban acompañados de un elenco más o menos detallado. Una especial comisión tenía el encargo de abrir las cajas y de anotar el contenido: lastimosamente, no tenía que señalar la proveniencia y ni el remitente. Después de esta operación de registro, el material pasaba a los varios pabellones a los que fueron destinados. Cabe subrayar que la mayor parte de esta documentación se ha perdido. ${ }^{31}$ En el caso del envío de objetos por parte de los salesianos de Ecuador, la congregación tampoco ha conservado el listado $-\mathrm{o}$, en todo caso, hasta ahora no lo hemos encontrado- de los objetos que enviaron para la exposición.

Conforme a lo afirmado por Sánchez Gómez, en el pabellón de etnología, organizado por Schmidt, se presentaba la interpretación de la vida humana por parte de la ciencia católica; ${ }^{32}$ la manera en la que se expusieron los objetos contribuía a dar a conocer esa interpretación, siendo el medio alrededor del cual se elaboraba el discurso misionero. En el pabellón de etnología la exhibición seguía el modelo de los ciclos culturales de Schmidt, que no tenía en cuenta la proveniencia de los objetos, ya que no se los organizaba ni exponía

29. John Considine, The Vatican Mission Exposition: A Window on the World (Nueva York: The MacMillan Company, 1925), 28.

30. Henry Dubois, citado en Laurick Zerbini, “Les expositions missionnaires, De l'objet-document à l'objet-mémoire". En La mission en textes et images XVI-XX'e siècles, ed. por Chantal Paisant, 273-290 (París: Karthala, 2004), 286.

31. Console, "Incontri tra culture...".

32. Sánchez Gómez, "Por la etnología hacia Dios...", 74-76. 
con este criterio. Lo que destaca de la manera en que fueron presentados son las similitudes entre los aspectos culturales en diferentes zonas del planeta. En suma, sin duda alguna, se estaba representando la teoría de los ciclos culturales de Schmidt. Precisamente, se puede ver cómo los muebles de la sala estaban organizados en cuatro vitrinas centrales y cuatro laterales. En las primeras dos centrales se exhibían objetos de las "civilizaciones primitivas centrales" (que incluía las que Schmidt definió como civilizaciones primitivas meridionales, las civilizaciones primitivas septentrionales, y las civilizaciones primitivas recientes). También se exhibían objetos de las "civilizaciones de nómadas ganaderos en Asia y África" (que incluían aquellas que se dedicaban a la gran caza y el totemismo, y otras que practicaban la agricultura en un sistema matriarcal). En las otras dos vitrinas centrales se representaban las civilizaciones secundarias, ${ }^{33}$ y más precisamente la "fusión de cazadores totemistas con agricultores matriarcales", la "fusión de ganaderos con agricultores matriarcales", la "fusión de ganaderos con cazadores totemistas" y la "fusión entre ganaderos, cazadores totemistas y agricultores matriarcales". La vitrina lateral de la derecha representaba las "similitudes entre períodos prehistóricos y ciclos culturales etnológicos" y la vitrina a la izquierda mostraba la "Colección prehistórica del Padre Huguemot" " ${ }^{34}$ Henry Dubois, quien detallaba la organización de las vitrinas, destacaba: "la etnografía, estudiada desde un espíritu imparcial, llega a la conclusión de que las poblaciones más primitivas están lejos de las más degradadas, y más bien son aquellas en que las muertes y los cultos son los más simples y los más puros. ${ }^{35}$

No es extraño que, en esta sala, y en varias otras, los objetos expuestos hubieran sido descontextualizados de su uso habitual para ser colocados en el orden establecido por Schmidt. Hay que matizar que los objetos no eran en sí mismos el foco de atención, pero sí lo era su función al interior de la vitrina que los exhibía y su funcionalidad al proyecto que la exposición defendía. Por ende, la primacía de la presentación en serie agilizaba la posibilidad de comparación exponiendo uno al lado del otro objetos similares utilizados por poblaciones diferentes y, al mismo tiempo, hacía intuir la falta de observación detallada sobre el objeto y su utilización. ${ }^{36}$

33. Término utilizado por la revista, que representa el encuentro entre civilización primitiva y civilización primaria. Siempre según lo expuesto en la revista, las civilizaciones primarias son las de los nómadas y los ganaderos en Asia y África.

34. "Il padiglione della etnologia e delle scienze ausiliari", Rivista Illustrata dell'Esposizione Missionaria Vaticana 2, n. ${ }^{\circ} 18$ (31 agosto de 1925): 579.

35. Henry Dubois, "L'exposition des missions", Revue d'Histoire des Missions 2 (abril de 1925), 18.

36. Laurick Zerbini, “Le musée missionnaire ethnologique du Latran. De la mission à l'ethnologie, un défi ambitieux", En Mission \& Science. Missiology revisited 1850-1940, ed. 


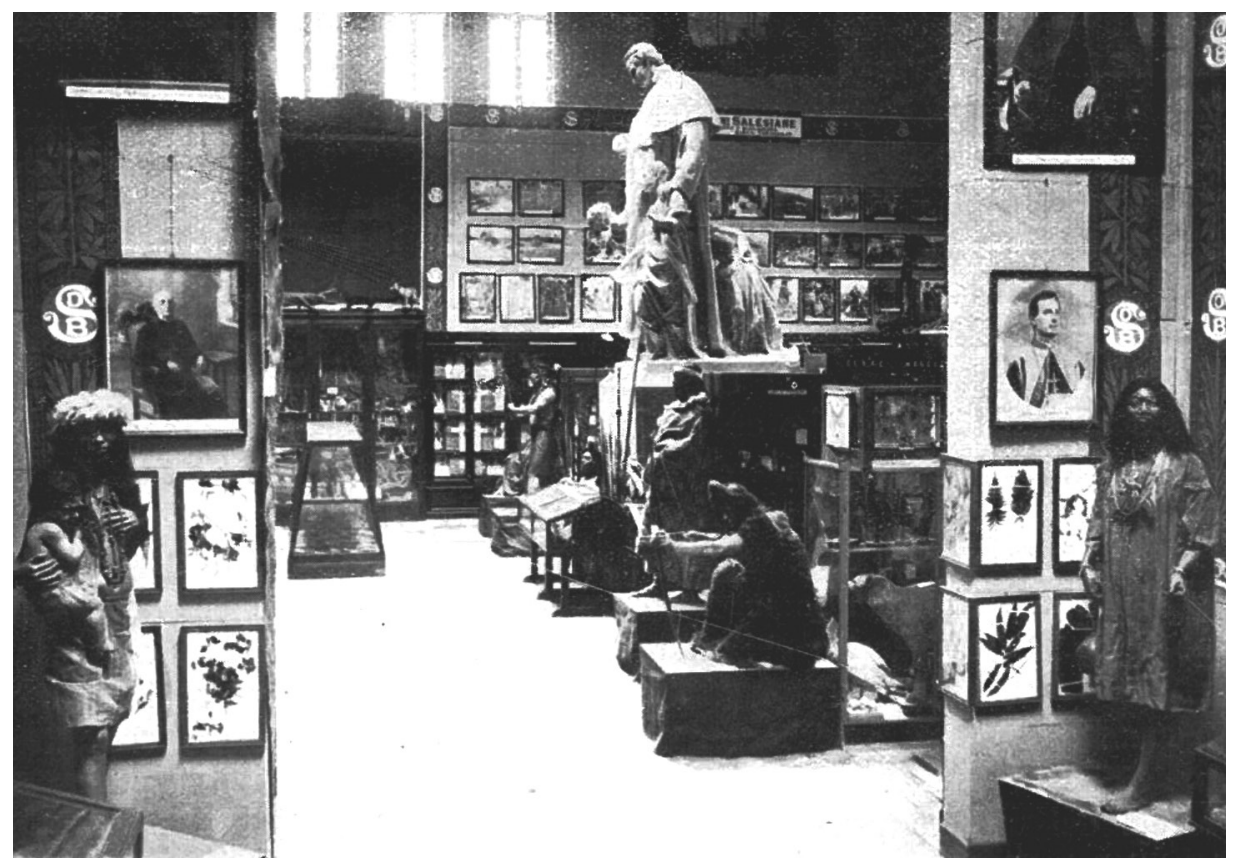

Figura 2. Mirada hacia la sala de América meridional.

Fuente: "Attraverso le sale", Rivista Illustrata dell'Esposizione Missionaria Vaticana 2, n. ${ }^{\circ}$ (15 de enero 1925): 88.

La descontextualización de los objetos ocurre también en otras partes de la exposición de las que Schmidt no fue encargado directamente. Por ejemplo, en la figura 2, una instantánea a la entrada de la sala de las misiones de América meridional, al lado de la exposición dedicada a la congregación salesiana, podemos entrever que el elemento central, el que domina sobre los otros, es la estatua de Don Bosco. ${ }^{37}$ Alrededor de él, en un plano inferior, se hizo una exhibición de varios objetos de los más variados, que incluia estatuas de personas, de animales y fotografías de los pueblos misionados por los salesianos en América meridional. En este punto se encuentran diferentes objetos provenientes de las misiones en Ecuador y en Brasil (en su mayor parte). De lo poco que se puede ver, puedo afirmar que el elemento central alrededor del cual se

por Carine Dujardin y Claude Prudhomme, 221-235 (Lovaina: Leuven University Press, 2015), 230.

37. Recordamos nuevamente que esta sala fue compartida entre misioneros salesianos, franciscanos y capuchinos. Cada uno de los institutos religiosos ocupaba una parte de la sala. 
articulaban los objetos en esta sección era la figura del sacerdote, lo que dejaba en un segundo plano a todos los otros elementos: las representaciones de seres humanos, los animales, los objetos materiales o el entorno natural, y que ello respondía a reafirmar, en coherencia con la lectura que querían facilitar los organizadores de la sala, la supremacía y la importancia de las labores que allí se estaban llevando a cabo por parte de los misioneros de la congregación.

Hay que destacar que entre el material que he podido consultar no he encontrado un listado detallado de los objetos expuestos en cada pabellón. Que estos detalles no hayan recibido una atención específica por parte de la Rivista Illustrata, a mi parecer, es particularmente significativo, pues simboliza un escaso interés por la publicación oficial de la Exposición de distinguir entre tal o cual objeto producido por tal o cual grupo misionado. Únicamente he encontrado un listado sumario en un artículo de Henry Dubois, que ha resultado de escasa ayuda debido a que, por ejemplo, no reporta detalle sobre la utilización de los objetos o sobre el grupo humano que los había producido. Finalmente, la falta de explicación detallada sobre los objetos expuestos en la sala de América meridional reconfirmaba el valor de los objetos no por lo que eran, sino por lo que contribuían a representar según el discurso misionero y la tentativa de uniformidad de las diferencias (entre órdenes misionales y pueblos misionados, por ejemplo) bajo el paraguas de la religión católica. ${ }^{38}$ Cabe destacar de qué manera en el discurso inaugural -reportado por la revista-el papa resaltó:

Hemos querido que el conjunto de las santas misiones, de esta obra realmente divina, fuera iluminado por una sola luz que hiciera destacar la belleza y la más delicada exigencia. Por esto hemos deseado que la parte científica, etnográfica, médica, literaria de las misiones tuviera un lugar importante porque [...] vivimos en tiempos en los que es evidente que no son suficientes los heroísmos y los sacrificios que acompañan la obra misional. Se necesita coger el fruto de la obra y del sacrificio de la mano de la ciencia para que venga a iluminarnos, a indicar los caminos más directos, a seguir las estrategias más proficuas. [...] Con estas palabras el Papa no sólo trazaba el programa de la Exposición [dice el periodista de la revista de la exposición misional], más bien dirige una invitación a todos los obreros de la obra apostólica a apoyarse en su acción cotidiana también en luz intelectual en general y en la ciencia de la misionología en particular. ${ }^{39}$

La Exposición reflejaba el interés dado en primer plano a la ciencia como fuente de legitimación del pensamiento y el accionar católicos, y también como estrategia para el futuro. Eso se expresó rotundamente cuando en el

38. Henry Dubois, "L'exposition...".

39. "Papa Pío XI inaugura la Mostra”, Rivista Illustrata dell'Esposizione Missionaria Vaticana 1, n. 2 (31 de diciembre 1924): 60. Por misionología se entiende la disciplina que estudia la evangelización, la actividad misional de la Iglesia y sus fundamentos teológicos. 
cierre de la Exposición el Papa Pío IX instituyó el Pontificio Museo Missionario Etnologico con sede en el Palazzo del Laterano, que acogería una selección de las obras expuestas, asegurando así la continuidad de esta recolección de objetos en el tiempo: "El hallazgo precioso que la generosidad y la abnegación de muchas almas han acumulado, y la inteligencia de tantos cooperadores así de bien dispuestos, no se perderá, sino que permanecerá como Museo Misional, como escuela, como un libro siempre abierto". ${ }^{40}$

El encargado de proyectar, organizar este nuevo museo, seleccionar las obras que iban a quedarse y aquellas que se devolverían a los diferentes institutos que las habían enviado para la exposición, fue el padre Schimdt, quien, además, dirigió el museo entre 1927 y $1939 .{ }^{41}$ En la segunda mitad de los años treinta, el padre Michele Schulien, también perteneciente a la Orden del Verbo Divino, y quien había sido segundo de Schmidt en la Exposición y en todas las otras actividades que siguieron, accedió a la dirección del museo. Hay que destacar que, a partir de 1937, el museo ayudó a la publicación del periódico Annali Lateranensi, que promovió el debate científico en lo que concierne a la etnología y a las misiones, y fue un instrumento de valorización de las colecciones museológicas.

\section{REPRESENTACIONES}

\section{DEL SURORIENTE ECUATORIANO}

En 1921 el doctor en Ciencias Naturales y sacerdote salesiano Carlo Crespi fue convocado a Turín para reunirse con el rector mayor, don Rinaldi; el responsable de las misiones, don Ricaldone; y el obispo del Vicariato de Méndez y Gualaquiza, monseñor Domenico Comín. Estos religiosos propusieron a Crespi su traslado a Ecuador para que, siguiendo el encargo de la nueva "oficina de propaganda" de la misión salesiana en el país andino, documentara "científicamente" los avances entre los "jíbaros" con miras a su presentación en la Exposición Misional Vaticana de 1924-1926 y en la exposición que los discípulos de Don Bosco preveían llevar a cabo en 1926 en Turín, en conmemoración del cincuenta aniversario de las Misiones Salesianas. ${ }^{42}$

Finalmente, Carlo Crespi partió del puerto de Génova a fines de marzo de 1923 llevando consigo 120 cajas de materiales y llegó a Guayaquil el 24 de

40. Citado en Pietro Ercole, "Dall'Esposizione Vaticana...", 10.

41. Cabe destacar que el debate entre difusionismo - del que Schmidt era exponente de primer plano- y el evolucionismo fue vigoroso durante las primeras dos décadas del siglo XX, para luego apaciguarse.

42. Sobre esta última exposición, véase Chiara Pagnotta, "La mise en scène...". 


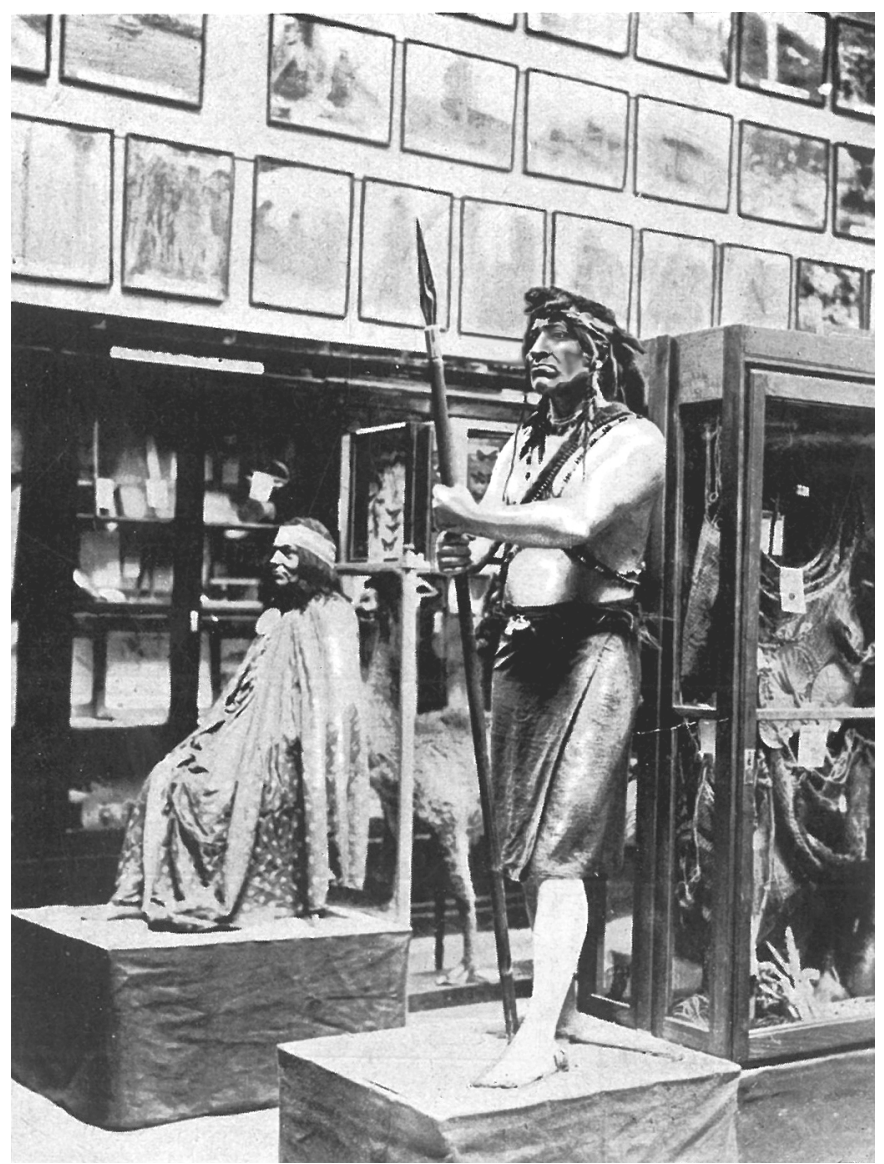

Figura 3. Misiones entre los jíbaros de Ecuador.

Fuente: "L'Esposizione Missionaria Vaticana". Supplementi alla Rivista Illustrata della Esposizione Missionaria Vaticana, n. ${ }^{\circ} 1$ (enero-febrero 1926): 6.

abril. ${ }^{43}$ Una vez en Ecuador, impartió conferencias que le permitieron recaudar fondos para el transporte de los materiales a Cuenca. Desde esta ciudad organizó las primeras excursiones a las zonas de Méndez, Gualaquiza e Indanza. Posteriormente, a finales de 1923 recibió desde Turín (la sede central salesiana) la orden de preparar el material para la Exposición Vaticana, para

43. No consta que estas cajas contuvieran material muy variado. Por ejemplo, contenían tejidos que fueron posteriormente repartidos entre la población indígena, y más en general, contenían material logístico, científico y sanitario. 
lo cual envió un abundante material etnográfico y documentación fotográfica. ${ }^{44}$

Los objetos recopilados por el salesiano fueron expuestos en diferentes espacios de la Exposición. La gran mayoría se encontraban en el pabellón de la América meridional, que era considerado por los comentaristas de la época como una de las salas más impresionantes de todas, debido a que las esculturas presentes proporcionaban al espacio una imagen de vida. ${ }^{45}$

En este caso, la Exposición Vaticana se distinguía de las varias exhibiciones que -en pasado y en futuro- tuvieron lugar en el mundo católico y en el mundo protestante. Ellas habían sido tristemente conocidas como "zoológicos humanos" por la exposición que se hacía de seres humanos "salvajes" en un simulacro de su ambiente natural, creado para satisfacer la curiosidad de los espectadores occidentales. En la Exposición Vaticana, al contrario, notamos que la recreación de una ambientación y un contexto "natural" se da con la presencia de varias estatuas. Al describir la escultura de un hombre "jíbaro" en la entrada del pabellón de América meridional, Dubois señala: "A vuestra llegada sois acogidos por un indígena que tiene conscientemente su arco para traspasarles"; y sigue aún más claramente: "Ya que ha sido conquistado su mundo, vuestro estremecimiento debe haberle dado por lo menos un mínimo de placer [al hombre jíbaro]" ${ }^{46}$

Tal vez, la emoción que suscite ahora el hombre con lanza sea diferente a la que suscitó en el observador de aquella época; en todo caso, las palabras de Dubois explicaban bien el papel que tenían que representar los indígenas de la Amazonía ecuatoriana dentro de la exposición. Además, no olvidemos la figura 2, en la que se ve claramente que la imagen masculina de la figura 3 estaba al lado, en un plano inferior a la imagen de Don Bosco, que dominaba esa parte de la sala. Se trataba de remarcar el miedo hacia el salvajismo de este pueblo y, en contraste, difundir la admiración y el apoyo hacia los misioneros que trabajaban para redimirlo. El mismo Bollettino Salesiano destaca cómo, en América Latina, únicamente los misioneros habían llegado hasta los pueblos "primitivos, salvajes e idólatras para redimir a los indígenas, remarcando en la ausencia de los gobiernos locales. ${ }^{47}$

Lo exhibido por los salesianos en esta sala provenía principalmente, pero no únicamente, de las misiones entre los shuar y los bororo. Acerca de las sa-

44. De este conjunto se ha podido encontrar escaso material en el Museo Etnológico Salesiano de Colle Don Bosco: unas cuatro cintas que se utilizaban como ornamento en las frentes de los hombres shuar.

45. Dubois, "L'exposition des missions", 238.

46. Ibíd.

47. "Visitando l'Esposizione missionaria Vaticana", Bollettino Salesiano n. 10 (octubre 1925): 255. 
las de América (del Norte y del Sur) recalcaba Dubois: "podemos así resumir la impresión de estas dos salas americanas: tipologías originales de indígenas, colecciones magnificas de historia natural, detalles interesantes de vida primitivas, dedicación de los misioneros, curas, hermanos y hermanas que corren en la búsqueda de almas al fondo de las tribus perdidas: estas son en síntesis las características de esta primera zona de apostolado". ${ }^{48}$

Cabe subrayar que en el patio del Vaticano, en el Cortile della Pigna, se encontraba la reproducción en tamaño normal de una "jibaría" en cuyo interior se hallaban algunas estatuas de los shuar representados en su quehaceres cotidianos. Las fotografías de esa reproducción, junto con otras que imagino pertenecientes al conjuntos de objetos exhibidos por los salesianos en la Exposición, acompañaban el artículo que la Rivista Illustrata della Esposizione Missionaria dedicaba precisamente a la misión salesiana "entre los jíbaros". ${ }^{49}$

Dieciocho fotografías acompañaban el artículo. Solo algunas, aquellas concernientes a la Exposición Vaticana, tienen una clara autoría, mientras que las otras (según se deduce) fueron tomadas por anónimos salesianos y tratan de escenificar la vida en la misión a partir de la descripción de sus habitantes. En la primera página del artículo, en el centro, aparece una imagen (figura 4) cuyo elemento predominante es monseñor Comín, rodeado de "cinco niños jíbaros de la Misión", dos parados al lado del salesiano y otros tres en cuclillas o agachados.

La figura de Comín aparece así en posición ligeramente elevada y central, para simbolizar el eje y contenido del artículo, es decir, el trabajo evangelizador de los salesianos con la población shuar.

Siguen un conjunto de fotografías que podríamos definir como de carácter etnográfico, en las que esán casi ausentes las figuras de los misioneros y tratando de representar a los shuar que habitaban el Vicariato, ya sea posando, ya sea durante sus quehaceres. En la segunda parte del artículo se presentan, también, imágenes más generales orientadas a mostrar a los lectores de la revista la vida en el Vicariato, en las que aparece la figura de un misionero durante una lección de catequesis a los shuar, la fotografía de un grupo de personas (no indígenas) durante una pausa, la de una visita de los indígenas a la misión, etc.

Los principales aspectos reportados en el artículo concernían tanto a los salesianos en el territorio del Vicariato como a una narración etnográfica del grupo "jíbaro", a partir de su organización social, económica, creencias y praxis social, entre otras:

48. Dubois, "L'exposition des missions", 241.

49. "Una missione salesiana tra i 'Jivaros' (Il Vicariato apostolico di Méndez i Gualaquiza)", Rivista Illustrata della Esposizione Missionaria 2, n. ${ }^{\circ} 8$ (31 de marzo de 1925): 227. Igualmente, la revista había dedicado otros numeros a presentar tal o cual misión a sus lectores, de manera similar al caso de nuestro interés. 


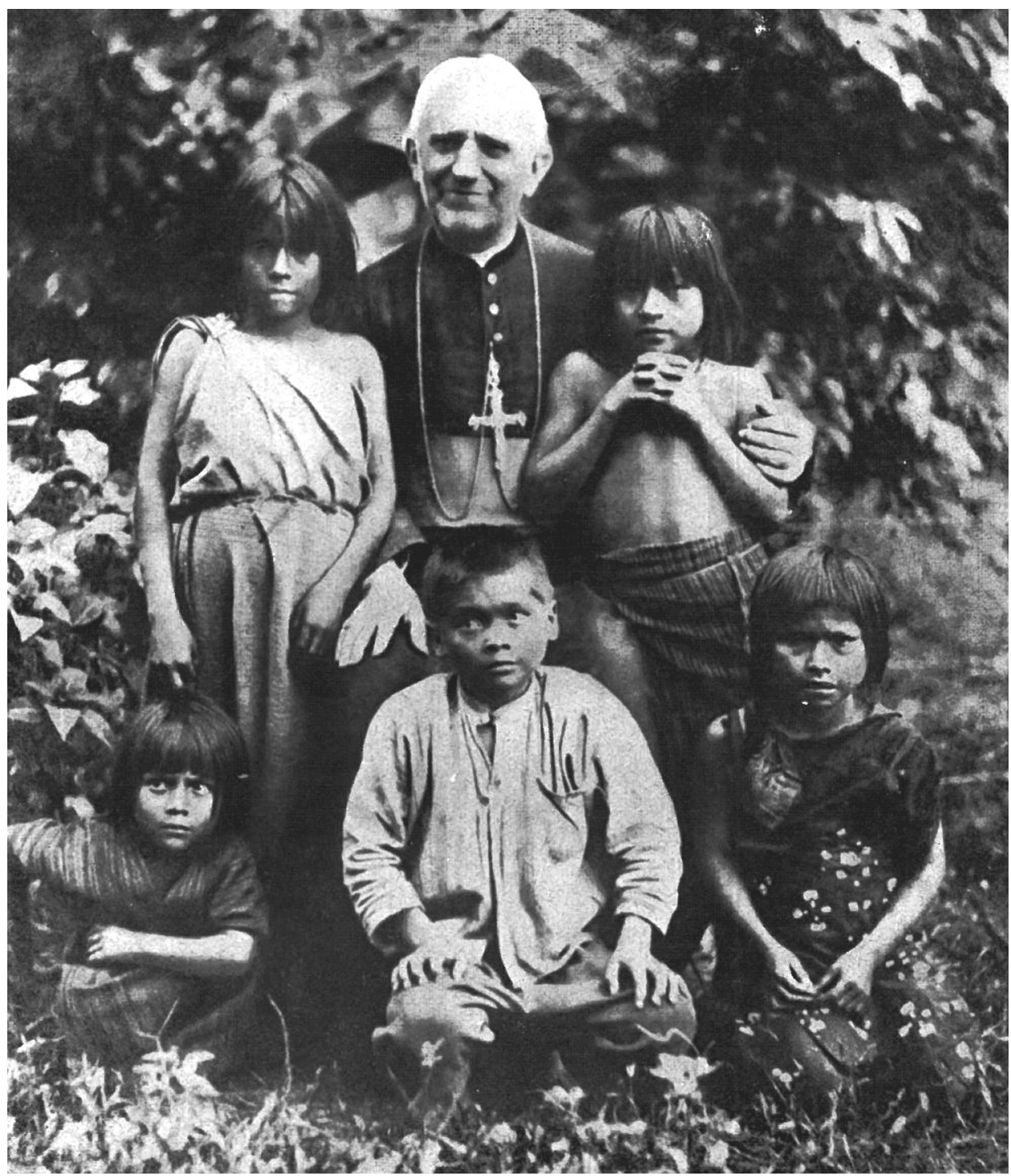

Figura 4. El vicario apostólico monseñor Comín con cinco niños jíbaros de la Misión. Fuente: "Una missione salesiana tra i 'Jivaros'. (Il Vicariato apostolico di Méndez i Gualaquiza)", Rivista Illustrata della Esposizione Missionaria 2, n. ${ }^{\circ} 8$ (31 de marzo 1925): 227. 
1. Confini del Vicariato. En este primer apartado se aclaraban los límites del Vicariato, presentando además la zona desde el punto de vista climático y geográfico.

2. La popolazione e la casa. Esta parte -la más extensa del artículo- trataba de la apariencia física de los "jíbaros" que: "entre todos los indios de Ecuador, son los más macizos y bellos".$^{50}$ Después de una descripción física se pasaba a describir sus ornamentos y tatuajes, para terminar con una afirmación que se encuentra en varias otras descripciones del grupo en la misma época: "Inteligentes, muy amantes de la libertad, incapaces de someterse a cualquier disciplina". ${ }^{51}$ Después, en el escrito se describían las vestimentas del grupo y nuevamente los ornamentos. Seguía un apartado sobre la organización habitacional del grupo y después su alimentación, destacando la producción y el consumo de la chicha. Luego, había un apartado sobre las armas utilizadas por el grupo.

3. Vita famigliare e sociale. Aquí se destacaba el espíritu vengativo del grupo, matizando cómo el jefe de cada familia cada mañana repetía el nombre de los enemigos, sus "barbaries y cómo estimula los hijos hacia la venganza". ${ }^{52}$ Además, la narración se enfocaba en explicar el poco amor al trabajo que tenían los hombres: "Él evita cuanto pueda el trabajo. Es mucho si se digna a cortar los árboles y a preparar su casa [...]. El día que el jíbaro tomará amor al trabajo y alejará de si el ocio, desaparecerá así un terrible obstáculo a su civilización: pero lastimosamente será necesario esperar más tiempo para esto, ya que el jíbaro desprecia cordialmente los trabajos campestres" ${ }^{53}$ Luego, se describía la poligamia masculina, la supuesta condición de inferioridad femenina, seguían unas palabras sobre la vida de los jóvenes y las relaciones colectivas al interior del grupo. En este apartado no podía faltar una descripción de la guerra y de la creación de las tzanzas, "la más alta manifestación de barbarie" 54 cuya fiesta concluye "con una verdadera orgía pagana". ${ }^{55}$

4. La lingua dei Jivari. Aquí se destacaba la falta de términos generales y abstractos y se reportaba un extracto en lengua (con su traducción) para explicar la sintaxis.

5. Religione e superstizioni. Se describía rápidamente la creencia en Taita Dios, del diablo, y se hablaba de la presencia de la brujería.

6. Gli inizi dell'opera di evangelizzazione. Empezaba aquí la descripción de la obra misional hacia el grupo y se destacaban las dificultades que habían

50. Ibíd., 228.

51. Ibíd.

52. Ibíd., 230.

53. Ibíd.

54. Ibíd., 231.

55. Ibíd. 
tenido las órdenes misionales anteriormente, en su obra en el Oriente ecuatoriano. En un segundo momento, se narraba el establecimiento de los salesianos en Gualaquiza.

7. Tra fatiche, speranze e disillusioni insistía en cómo el sentimiento de venganza y las luchas intestinas fueron el obstáculo más grande a la conversión. Luego, el narrador ilustraba la historia de la misión de Gualaquiza llevada a cabo los primeros años, y unos episodios de vida en la misión de los que se destacaban las dificultades que los salesianos encontraban en su obra con el grupo indígena.

8. Il bilancio del primo decennio. Se hablaba de la llegada en 1902 de las hijas de María Auxiliadora y se describían los primeros tímidos resultados, explicando que ahora la tzanza no era mostrada en público como trofeo de guerra; las guerras y la poligamia habían sido disminuidas en número, etc. Luego, se revelaba cómo los salesianos habían presentado en 1906 un pedido de apoyo al gobierno ecuatoriano, junto con un censo de los jíbaros y una explicación de los logros "civiles" obtenidos (construcción de casas, colonia agrícola, mercado semanal de comercio, abertura de carreteras, etc.). Por último, se presentaba el jíbaro Giovanni Bosco como demostración de los logros de los misioneros hacia la conversión de los "jíbaros".

9. Le nuove fondazioni. Se relata la visita a Bomboiza por parte de padre Allioni, y unos otros pocos acontecimientos que parecían haber frustrado los logros salesianos en la evangelización del grupo indígena; se detallaba luego la fundación de las misiones de Indanza y de Méndez, así como las de unos puentes para facilitar el trabajo misionero, y la realización de otras obras civiles.

10. Lo stato attuale. En este apartado conclusivo se trazaban las líneas del trabajo que quedaba por hacer en medio de las dificultades causadas, ya fuera por el carácter del jíbaro "cauteloso hacia todos [...] sumergido en su vida carnal, en su ociosidad y sensualidad [...]", ya fuera por el ambiente: "llueve seis meses al año [...] la agua rende impenetrables los pocos senderos e infla los ríos que devienen invadeables [...] el misionero se mueve cuando puede". ${ }^{56}$

Evidentemente, el artículo estaba enfocado en presentar las labores de los misioneros a un público amplio de lectores, a menudo no familiarizados con la vida misionera en el suroriente ecuatoriano. Hay que destacar que el artículo no hace hincapié en el trabajo que los salesianos hacían con los colonos asentados en la zona del Vicariato. El foco está dirigido a las laborares evangelizadoras y civilizadoras de los "salvajes" shuar, sin lugar a duda, y esto parecía funcional al resaltar la figura del "heroico" misionero tal y como se hacía en su parte final. 


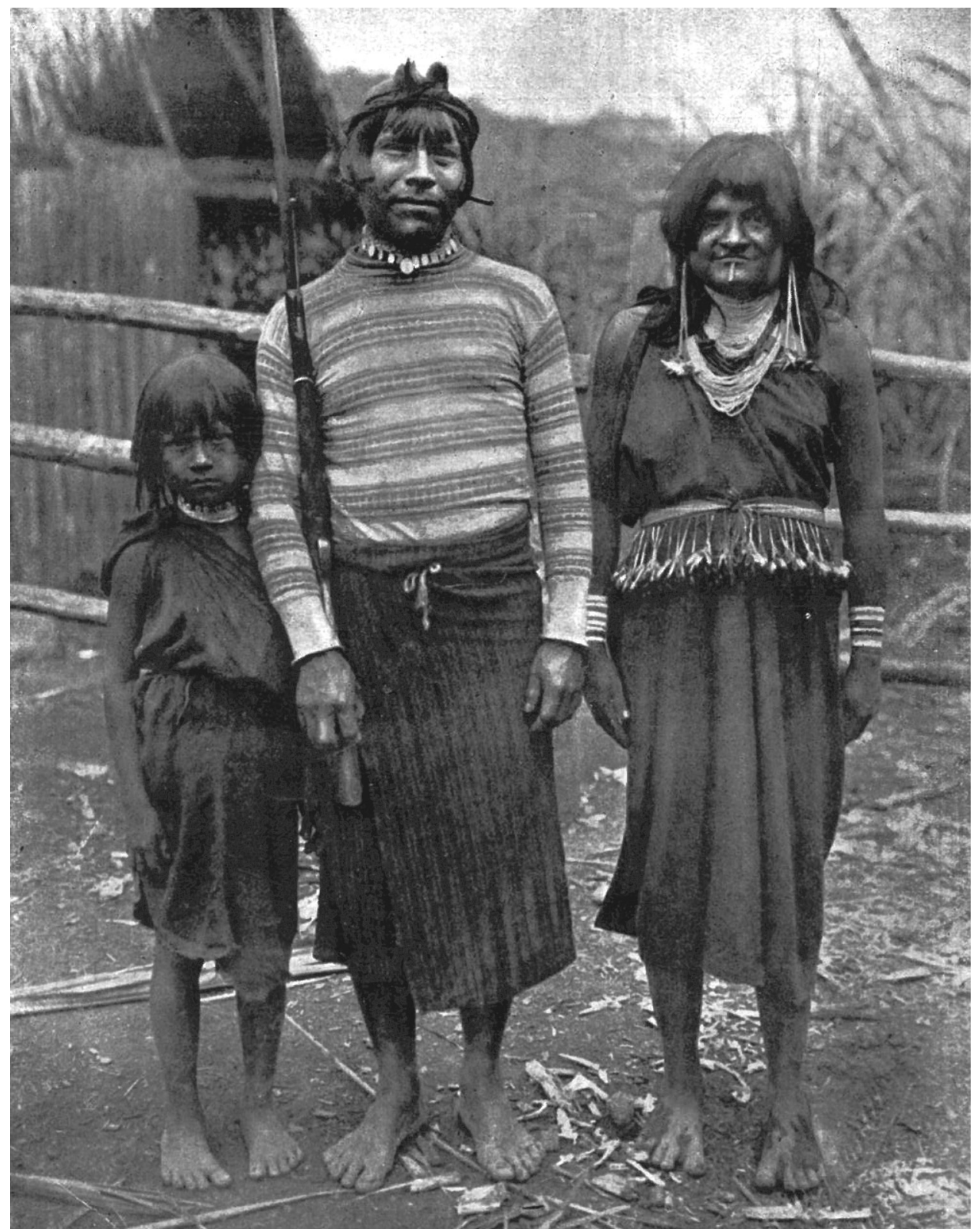

Figura 5. Las primicias del Apostolado: Giovanni Bosco con su familia. Fuente: "Una missione salesiana tra i 'Jivaros'. (Il Vicariato apostolico di Méndez i Gualaquiza)", Rivista Illustrata della Esposizione Missionaria 2, n. ${ }^{\circ} 8$ (31 de marzo 1925): 237. 
A mi parecer, un elemento importante del escrito, que tiene su reflejo también en la fotografía, es la presentación que se hace del shuar llamado Giovanni Bosco.

El artículo nos recuerda que el shuar había acompañado a don Mattana en uno de sus viajes hacia Italia. Este hombre era "La primicia de su apostolado, al que él [Don Mattana] había impuesto el nombre de Giovanni Bosco", ${ }^{57}$ y que, una vez de regreso a Ecuador, según lo que consta en el artículo, se había convertido en "el padre de una familia cristiana" ${ }^{58}$

El dato particularmente significativo, a nuestro parecer, es que esta fotografía no se encuentre junto al texto escrito sobre el tema, sino que se ubique en la última página del artículo, como para representar idealmente el cierre del recorrido hacia la evangelización, que empieza con la obra salesiana entre los niños (figura 5) y termina con el triunfo del proyecto misionero, es decir: la formación de una verdadera familia monógama y cristiana. Esta imagen atestigua, entonces, la civilización alcanzada por los shuar y la fuerza de las labores salesianas en la batalla contra la poligamia.

Finalmente, hay que destacar que en el pie de página de este largo reportaje sobre los salesianos y los "jíbaros" se reportaban noticas sobre la fuente del artículo. Los salesianos habían entregado a la revista un boceto de un libro de próxima publicación que había sido la base sobre la que se escribió el reportaje. ${ }^{59}$ Recalcar que se trataba, por parte vaticana, de la reposición de la imagen del territorio misionado y de sus habitantes que presentaban, en Ecuador y en el mundo católico, y en las primeras décadas del siglo XX, a los padres salesianos. ${ }^{60}$

Nos parece particularmente emblemático que la representación de una particular congregación misional fuera asumida como propia por parte de la revista oficial de la Exposición. Cabe destacar que la práctica de publicar artículos sobre las experiencias de las comunidades u órdenes misioneras, en un determinado territorio, era algo frecuente en la revista. En el caso que nos interesa, esta puede sugerir alguna pista de interpretación: por un lado,

57. “Una missione salesiana tra i 'Jivaros': 237.

58. Ibíd.

59. Ibíd. Desconozco las referencias más precisas sobre este libro y si salió a la luz. De otro lado, he encontrado el borrador del manuscrito que dio origen al artículo referido. La autoría del borrador es de don Albino del Curto (mientras que en la versión revisada y luego impresa por la revista, no aparece indicación alguna sobre la autoría final). Véase Albino del Curto, Rivista Illustrata della Esposizione Missionaria Vaticana, Archivo Documental y Fotográfico Salesiano (Quito), caja Documentos y material Histórico sobre misioneros VI - Del Curto - I.

60. Véase, entre otros: Chiara Pagnotta, "The nationalization of the Ecuadorian Amazon in the early twentieth Century: The Salesian outpost". En Legacies of Conquest, ed. por David Midgley, Jenny Mander y Christine Beaule (Londres: Routledge, en prensa). 
se podría interpretar como una confirmación del aval del Vaticano hacia las labores misionales de la Congregación Salesiana. Contemporáneamente, reforzaría la convicción de que la exhibición había sido pensada como un instrumento más para unificar -bajo las jerarquías de la Iglesia católica- a las distintas organizaciones misioneras, ${ }^{61}$ dando noticias de sus obras y haciéndolas así parte de una estructura más grande, y ensalzando el valor general de las misiones y de los misioneros, de los sacrificios que padecían por el bien mayor de la conversión de los "salvajes". Se afirmaba, así, la potencia y actualidad de la creencia religiosa.

\section{ConClusiones}

En este artículo he intentado hacer una aproximación a la representación del suroriente ecuatoriano y de sus habitantes, promovida a nivel internacional por los salesianos en la Exposición Misional Vaticana de 1924-1926, a través de la exhibición de los objetos y materiales provenientes del territorio del Vicariato Apostólico de Méndez y Gualaquiza. He tratado aquí, únicamente, la imagen propuesta en ocasión de la participación de la congregación en dicha exposición, en la que además participaban varios institutos misioneros, dejando de lado otras exposiciones que tuvieron lugar en la misma década y que tuvieron como organizadores / expositores únicamente a los salesianos. ${ }^{62}$

Se puede, sin duda, decir que la Exposición Misional Vaticana fue un espacio de representación que no permitió a la congregación salesiana destacar autónomamente su voz y su específico proyecto en el territorio del Vicariato de Méndez y Gualaquiza.

Por un lado, creo haber demostrado que no era casual la poca importancia dada a uno $\mathrm{u}$ otro instituto misional en un espacio determinado. Se trataba, a mi parecer, de reafirmar la potencia unificadora de la Iglesia poniendo en la sombra las diferencias internas. La pretendida uniformidad de los "heroicos" misioneros y de los "salvajes" misionados no es casual, más bien refleja un intento de legitimar la presencia de las misiones en las diferentes partes del mundo que expresan las mismas necesidades de evangelización.

De otro lado, creo haber demostrado que el foco central de la Exposición Vaticana no fue la representación de la alteridad de los pueblos misionados, sino el trabajo misionero desarrollado entre los "salvajes", incluyendo entre ellos a los "jíbaros" del Vicariato de Méndez y Gualaquiza, y muchos otros pueblos. En este sentido, representar un determinado grupo, en un preciso

61. Dedicando a ellas artículos específicos de la revista.

62. Temáticas que son objetos de otros trabajos de mi autoría. 
momento o actuación como, en nuestro caso, un hombre shuar con la lanza en su mano, significaba no tanto dar importancia a este particular grupo indígena, a sus usos, costumbres y a su historia, sino enfatizar en su ferocidad para dar a conocer las duras labores y condiciones de vida padecidas por los héroes misioneros que llevaban el catolicismo a las tierras más remotas. Igualmente, la publicación del artículo sobre la misión entre los shuar es enfocada alrededor del mismo dualismo.

Ya en la disposición de los objetos exhibidos se puede entender una estrategia con miras a restablecer el primado de la Iglesia, haciendo de la Exposición un instrumento de propaganda para este fin. La serialidad que subyace en la organización de las vitrinas pone a la luz las similitudes entre objetos diferentes y producidos por diferentes grupos, pero misionados por la misma congregación u orden, tratando así de hacer ver la uniformidad -para los ojos del organizador de las vitrinas- hacia los diferentes grupos misionados. Esto se verifica en varios pabellones y, de manera particular, en el pabellón de etnología.

Para finalizar, hay que destacar que los objetos expuestos por los franciscanos y los capuchinos -que compartían la sala de América meridional con los salesianos- merecerían ser tema de un estudio más específico para poder trabajar de forma comparativa las representaciones de la América meridional de los pueblos misionados, y de los diferentes grupos misioneros que encontramos en la Exposición Misional Vaticana.

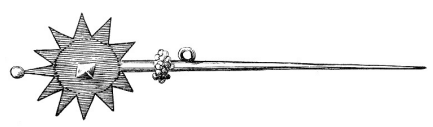

\section{FUENTES Y BIBLIOGRAFÍA}

\section{Archivos}

Archivo Documental y Fotográfico Salesiano de Quito (Ecuador).

Archivio Salesiano Centrale en Roma (Italia).

Museo Etnologico Missionario di Colle Don Bosco (Italia).

FUENTES PRIMARIAS PUBLICADAS

Annali Lateranensi (1937).

Bollettino salesiano (1925).

El Siglo de las Misiones (1929). 
Revue d'Histoire des Missions (1925).

Rivista Illustrata della Esposizione Missionaria Vaticana (1924-1926).

Supplementi alla Rivista Illustrata della Esposizione Missionaria Vaticana (1926).

\section{FUENTES SECUNDARIAS}

Abbattista, Guido. Umanità in mostra. Esposizioni etniche e invenzioni esotiche in Italia (1880 1940). Trieste: Edizioni Università di Trieste, 2013.

Aimone, Linda y Carlo Maria Olmo. Le esposizioni universali, 1851-1900: il progresso in scena. Turín: Umberto Allemandi \& Co., 1990.

“Attraverso le sale". Rivista Illustrata dell'Esposizione Missionaria Vaticana 2, n. 3 (15 de enero de 1925): 87-90.

Bottasso, Juan. Los salesianos y la Amazonía. Actividades y presencia. T. III. Quito: AbyaYala, 1993.

. Los salesianos y la Amazonía. Relaciones etnográficas y geográficas. T. II. Quito: Abya-Yala, 1993.

coordinador. Los salesianos y la Amazonía. Relatos de viaje. 1893-1909. T. I. Quito: Abya-Yala, 1993.

Burke, Peter. Eyewitnessing. The Uses of Imagies as Historical Evidence. Londres: Reaktion Books Ltd, 2001.

Bury, John. The Idea of Progress: An Inquiry Into Its Origins and Growth. Nueva York: Dover Publications, 1932.

Chartier, Roger. "Le monde comme représentation". Annales. Économies, Sociétés, Civilisations 44, n. ${ }^{\circ} 6$ (1989): 1505-1520.

Considine, John. The Vatican Mission Exposition: A Window on the World. Nueva York: The MacMillan Company, 1925.

Console, Ester Maria. "Incontri tra culture nelle collezioni del Museo Missionario Etnologico". En I Musei vaticani 1929-2009: nell'80 anniversario della firma dei Patti lateranensi, editado por Antonio Paolucci y Cristina Pantanella, 169-178. Roma / Florencia: Musei Vaticani / Giunti \& Livorno / Sillabe, 2009.

“D. Bosco e i Salesiani nella Repubblica dell'Equatore”. Bollettino Salesiano XI, n. 9 (septiembre de 1887): 105-106.

Dubois, Henry. "L'exposition des missions". Revue d'Histoire des Missions 2 (abril 1925): 213-311.

García Jordán, Pilar. "Los Chiriguanos en la Esposizione d'Arte Sacra e delle Missioni e delle Opere Cattoliche en Turín, 1898”. En El mundo latinoamericano como representación, siglos XIX-XX, editado por Pilar García Jordán, 81-106. Barcelona: Ediciones UB / TEIAA / Instituto Francés de Estudios Andinos, 2015.

Greenhalgh, Paul. Ephemeral Vistas: The Expositions Universelles, Great Exhibitions and World's Fairs, 1851-1939. Manchester: Manchester University Press, 1988.

Gruzinski, Serge. La guerre des images de Christophe Colomb à "Blade Runner" (14922019). París: Fayard, 1990.

"I campi delle missioni estere salesiane". Bollettino Salesiano XLVIII, n. ${ }^{\circ}$ (febrero 1924): 35-37.

"Il padiglione della etnologia e delle scienze ausiliari", Rivista Illustrata dell'Esposizione Missionaria Vaticana 2, n. ${ }^{\circ} 18$ (31 de agosto 1925): 576-579. 
Karsten, Rafael. The Head-hunters of Western Amazonas. The Life and Culture of the Jibaro Indians of Eastern Ecuador and Peru. Helsinki: Societas Scientiarum Fennica, 1935.

“L'Esposizione Missionaria Vaticana". Supplementi alla Rivista Illustrata della Esposizione Missionaria Vaticana, n. ${ }^{\circ} 1$ (enero-febrero 1925): 1-7.

"L'organizzazione della mostra". Rivista Illustrata dell'Esposizione Missionaria Vaticana 1 (15 de diciembre 1924): 19-28.

La Direzione [de la revista]. "Lo spirito ed il programma della nostra rivista". Rivista Illustrata dell'Esposizione Missionaria Vaticana 1 (15 de dicembre 1924): 1-7.

Lang, Andrew, The Making of Religion. London, Nueva York \& Bombay: Longmans Green \& Co, 1898. https://ia601407.us.archive.org/13/items/makingofreligion00langiala/makingofreligion00langiala.pdf.

Lanternari, Vittorio. Antropologia religiosa. Etnologia, storia, folklore. Bari: Edizioni Dedalo, 1997.

Leone, Alba Rosa. "La politica missionaria del Vaticano tra le due guerre". Studi Storici 21, n. $^{\circ} 1$ (1980): 123-156.

López-Ocón, Leoncio. "La América Latina en el escenario de las Exposiciones Universales del Siglo XIX". Procesos: revista ecuatoriana de historia, n. ${ }^{\circ} 18$ (enerojunio 2002): 103-126.

Marin, Louis. Des pouvoirs des images. París: Éd. du Seuil, 1993.

Monsignor Ercole Pietro. Direttore Ammnistrativo del Museo, “Dall'Esposizione Vaticana al Museo Missionario Etnologico del Laterano", Annali Lateranensi I (1937): 9-12.

Muratorio, Blanca. "Ensayo introductorio: En la mirada del otro". En Retrato de la Amazonía. Ecuador 1880-1945, editado por Lucía Chiriboga, 13-27. Quito: Libri Mundi / Enrique Grosse-Luemern, 1992.

. "Nación, identidad y etnicidad: imágenes de los indios ecuatorianos y sus imagineros a fines del siglo XIX". En Imágenes e imagineros. Representaciones de los indígenas ecuatorianos, siglos XIX y XX, editado por Blanca Muratorio, 109196. Quito: FLACSO Ecuador, 1994.

Nora, Pierre. Les lieux de mémoire. París: Gallimard, 1997.

Pagnotta, Chiara. " 'Evangelizar' y 'civilizar' la Amazonía ecuatoriana. Una aproximación a la actividad del salesiano Carlo Crespi en la década de 1920". En La reinvención de América. Siglos XIX-XX, editado por Pilar García Jordán, 125-149. Barcelona: Edicions UB / TEIAA, 2017.

. "La mise en scène del proyecto salesiano en el suroriente ecuatoriano. La Exposición Etnográfica del Oriente (Guayaquil, 1924) y la Exposición Misional Salesiana (Turín, 1926)", inédito.

. "Los salesianos y los jíbaros. Imágenes sobre el primer viaje de exploración al Oriente ecuatoriano (1893)". En El mundo latinoamericano como representación, siglos XIX-XX, editado por Pilar García Jordán, 57-176. Barcelona: Ediciones UB / TEIAA / Instituto Francés de Estudios Andinos, 2015.

. Situando los márgenes de la nación. Los italianos en Ecuador (XIX-XX). Quito: AbyaYala / TEIAA, 2016. 
. "The nationalization of the Ecuadorian Amazon in the early twentieth Century: the Salesian outpost". En Legacies of Conquest, editado por David Midgley, Jenny Mander y Christine Beaule. Londres: Routledge, en prensa.

"Papa Pío XI inaugura la Mostra". Rivista Illustrata dell'Esposizione Missionaria Vaticana 1, n. ${ }^{\circ} 2$ (31 de diciembre 1924): 59-61.

Poole, Deborah. Vision, Race and Modernity. A Visual Economy of the Andean Image World. Princeton: Princeton University Press, 1997.

Rivet, Paul. "Les Indiens Jibaros. Etude géographique, historique et ethnographique". L'Anthropologie 19 (1907): 333-368.

Rossi, Cesare y Marco Boroli. Calendario Atlante delle Missioni Cattoliche. Esposizione Missionaria Vaticana. Novara: Istituto Geografico De Agostini, 1925.

Sánchez Gómez, Luis Ángel. "Por la etnología hacia Dios: la Exposición Misional Vaticana de 1925". Revista de Dialectología y Tradiciones Populares LXII, n. ${ }^{\circ} 2$ (julio-diciembre 2007): 63-107.

Schmidt Guillermo. Manual de historia comparada de las religiones. Origen y formación de la religión. Teorías y hechos. Madrid: Espasa Calpe, 1941.

Taylor, Anne-Christine. "El Oriente ecuatoriano en el siglo XIX: 'el otro litoral'”. En Historia y región en el Ecuador: 1830-1930, editado por Juan Maiguashca, 17-68. Quito: FLACSO Ecuador / York University / Instituto Francés de Estudios Andinos / Corporación Editora Nacional, 1994.

. “Una categoría irreducible en el conjunto de las naciones indígenas: Los Jíbaros en las representaciones occidentales". En Imágenes e imagineros. Representaciones de los indígenas ecuatorianos, siglos XIX y XX, editado por Blanca Muratorio, 75-107. Quito: FLACSO Ecuador, 1994.

The metropolitan Museum of Art - New York. The Vatican Collections: The Papacy and Art. Nueva York: Harry N. Abrams, Inc., Publisher, 1984.

"Una missione salesiana tra i 'Jivaros'. (Il Vicariato apostolico di Méndez i Gualaquiza”, Rivista Illustrata della Esposizione Missionaria 2, n. ${ }^{\circ} 8$ (31 de marzo 1925): 227-237.

Vázquez, Lola, Juan Fernando Regalado, Blas Garzón, Víctor Hugo Torres y José E. Juncosa, coordinadores. La presencia salesiana en Ecuador. Perspectivas históricas y sociales. Quito: Abya-Yala, 2012.

"Visitando l'Esposizione missionaria Vaticana". Bollettino salesiano n. ${ }^{\circ} 10$ (octubre 1925): 255-256.

Zerbini, Laurick. "Le musée missionnaire ethnologique du Latran. De la mission à l'ethnologie, un défi ambitieux". En Mission E Science. Missiology revisited 18501940, editado por Carine Dujardin y Claude Prudhomme, 221-235. Lovaina: Leuven University Press, 2015.

. "Les expositions missionnaires, De l'objet-document à l'objet-mémoire". En La mission en textes et images XVI-XXe siècles, editado por Chantal Paisant, 273-290. París: Karthala, 2004. 